\title{
Commerce Ethics of Muhammad PBUH' and Universal Values in Era of Prophet Hood
}

\author{
Suwandi \\ PhD Candidate in Islamic Business, National University of Malaysia \\ No. 20, Jalan 3, Taman Jelok Indah, 43000 Kajang-Selangor-Malaysia. \\ Sw4ndi@yahoo.co.id
}

\begin{abstract}
Muhammad PBUH, primarily business along with his father since as early as his childhood. Whilst he grown up, he commenced to setup his own venture and also have a joint venture with Siti Khadijah based on mudharabah scheme. He is gifted with great wisdom in trading and has allowed him gaining great benefit through it. Due to his moral in trading, it leads to his marriage with Siti Khadijah. Unquestionably there were features on the ethics and morals in the trade that Muhammad PBUH has represented. A matter of concern was his morality that shown during trade leads to his marriage with Siti Khadijah who was initially his business colleague previously and what was the commercial strategy that empowers him to a vast profit during trading. Thus, this study endeavor to define and detail the ethics and morals in trading that has been shown by Muhammad PBUH prior his prophet hood. The results of this study display the conflicting fact in practices that has been applied amongst the community back at that time. His abundant in honest, fairness, friendly and compassionate to the buyer, and never set up a high price, and also detail in transaction record consequential him loved by many people. Alongside the combination of his aptitude in negotiation and intelligence, he was proficient to "read" the market opportunities and learning cultural and geographical conditions of each target market led him to higher profits than other merchants. In addition, this study also articulated sixteen Muhammad PBUH' universal values in commerce such; honest, trustworthy, fair, polite and affectionate in trade, buy-sell applies only based on mutual consent, not involved in usurious practices', only legitimate and permitted item that will sell, avoid argument with partners and buyers, no oath in the name of idols, hoarding the goodies (ikhtisar) is not allowed, damaged item' replacement policy, avoid competition on price, small profits is acceptable, pay his employee as soon as the job is done, always record transaction, and be generous. Those ethics and values actually resemble to such practice by Islamic merchants to highlight Islamic values in commerce nowadays.
\end{abstract}

Keyword: Trading Business Ethics, Muhammad PBUH, prior to prophet hood.

\begin{abstract}
Abstrak
Muhammad SAW merupakan pelaku bisnis bersama pamannya sejak masa kecilnya. Setelah beranjak dewasa beliau memulai usaha sendiri dan juga memiliki kerjasama dengan Siti Khadijah berdasarkan skema mudharabah., penelitian ini berusaha untuk mendefinisikan dan membahas etika dan moral dalam perdagangan yang telah ditunjukkan oleh Muhammad SAW sebelumnya era kenabian. Hasil studi ini menampilkan fakta bertentangan dalam praktek-praktek yang telah diterapkan di masyarakat arab pada waktu itu. Beliau merupakan pedagang yang jujur, adil, ramah dan penyayang kepada pembeli, dan tidak pernah menetapkan atas harga tinggi, dan juga detail dalam mencatat transaksi sehingga dia dicintai oleh banyak orang. Di sisi nabi Muhammad berbakat dalam negosiasi dan intelijen, dia mahir untuk "membaca" peluang pasar dan belajar kondisi geografis dan budaya masing-masing target pasar membawanya keuntungan yang lebih tinggi dari pedagang lain. Selain itu, kajian ini juga menjelaskan enam belas nilai universal dalam perdagangan tersebut; jujur, dapat dipercaya, adil, sopan dan penuh kasih sayang dalam perdagangan, Jual-Beli hanya berdasarkan musyawarah untuk mufakat, tidak terlibat dalam praktek riba, sah dan diperbolehkan hanya item yang akan menjual, menghindari debat dengan
\end{abstract}


mitra dan pembeli, tidak ada sumpah dalam nama berhala yang berlaku, penimbunan barang (ikhtisar) adalah tidak diperbolehkan, kebijakan penggantian, menghindari kompetisi pada harga, keuntungan kecil diterima, membayar karyawan nya segera setelah pekerjaan yang dilakukan, selalu catatan transaksi, dan bermurah hati. Etika dan nilai-nilai yang benar-benar mirip praktek seperti oleh pedagang Islam untuk menyoroti nilai-nilai Islam dalam perdagangan saat ini.

Kata kunci: etika bisnis Perdagangan, Muhammad SAW, sebelum era kenabian.

\section{INTRODUCTION}

During Jahiliyyah era, views on moral and value, good or bad, as well as halal (permitted) and haram (prohibited) in the economy was the result of human thought that are madeto-measure the justice the interests of certain individuals and groups. Undistinguished, the outlook of secular science, ideas about morals and values are the product of human thought as well. It is caused by a thought that moral science is a science of its own and separate from the mother of nature of science and technology itself. Though Adam Smith himself admitted that the foremost contribution of religion is the process of economic development and commerce is the value of religion itself as a moral enforcement mechanism. Nevertheless, Smith's confession appears conflicted with the invisible hand theory that believes man as a creature of self-interest of the morality and religion unrelatedly.

According to Kenneth Lux (1990), from secular perspective, study of the economics and morality are separate due to involving the revelation into the study is considered as unscientific. Thus, this secular thought as the cause of the existence of Jahiliyyah commerce system in modern form. 1434 years ago before the advent of the Prophet Muhammad, in Jahiliyyah era also applies this particular commerce system that ignores the moral and ethics, commerce system that vindicates any means to gain profit.

The study on the ethics and values of Islam commerce has been talked in recent. At one point, the author comprehend that those studies focused only on the ethics by al-Quran and al-Hadith. Temporarily, on the other hand the fact is Muhammad PBUH' commerce applied before prophet hood whereas prophet only three times conduct sales, and the rest is a purchasing transaction afterwards. This is also recognized by the hadith of the Prophet
"I was not given a revelation to hoard wealth or to become a trader amongst you (18: $309 \mathrm{w})$.

Previous studies referred as the following: Economics study as a moral science that derives from al-Quran and al-Hadith as it was taught and represented entirely by the prophet Muhammad has been studied by the great Islamic thinkers such as Abu Yusuf (died th. $182 \mathrm{H}$ ), Yahya bin Adam (died th. $303 \mathrm{H}$ ), alGhazali (died 505 AH), Ibn Rushd (died th. 595 H), al-'Izz bin 'Abd al-Salam (died th. $660 \mathrm{H}$ ), alFarabi (died th. $339 \mathrm{H}$ ), Ibn Taymiyah (died th. $728 \mathrm{H}$ ), al-Maqrizi (died th. $845 \mathrm{H}$ ), Ibn Khaldun (died th. 808 H), MA Mannan (1970), Nejatullah Siddiqi (1988), Afzalurrahman (1975), Umar Chapra (2000), and Khurshid Ahmad (1981), as well as many others Islamic scholars. Nonetheless, we found very few studies by experts and scholars talking on Muhammad PBUH' commerce behaviours especially prior to the prophet hood. Consequently, this paper objective is to examine the universal ethics and values of commerce prior to prophet hood of Muhammad PBUH by the literature method (library research), the historical method research and also the method of comparison (comparative research).

This study is imperative due to the actual practicing of commercial practices exemplified by Muhammad PBUH applies before the prophet hood. In addition, this study is very important since we perceive that most merchants today are losing moral and ethics in the business, so it is reasonably difficult to distinguish between Islamic trader and non-Islamic merchants (western/conventional merchants). Unethical business behavior happening to almost all countries, such as Mitsubishi Electric, Japan who experiencing the delay during its TV product removed from the market after they learnt that the tv was causing overheat and fire. Nike Company pays low labor costs in various 
developing countries to make shoes that are one of the highest selling prices in the market for sport shoes. In Indonesia, the unethical business practices more visible after the collapse of the New Order in early 1998. The case of Edi Tanzil, BLBI (Bank Indonesia Liquidity Assistance), PT Newmont, Freeport and the latest case is Century that hostiles Central Bank up to 6.5 trillion rupiah. Malaysia is experiencing the same, case of $1 \mathrm{MDB}$ Haj Saving that is considered detrimental to the people so that people losing confidence with the government. In Europe, the company who ignores ethics, for example; Enron, Merck, Xerox, Global Crossing, Rite-Aid, Oracle, ParMor, AOL Time Warner, Citigroup and others. One of the reason this happen is because merchants today especially Islamic merchants no longer have debuted entrepreneurs whom upholding moral values and ethics who possible as a role models in implementing commercial activities.

\section{THE CONCEPT OF COMMERCE ETHICS}

Commerce is a series of activities comprised of exchange, buying-selling, spending, marketing, working and mutual interaction with other human beings in order to develop benefits. Thus, commerce is a very broad activity. It includes minerals or agricultural activity of natural resources, processing raw materials, making various goodies, distribution, services provider, buy and sell good, or any other activity that associated with a work that objectives to gain result (profit).

Ahmad Munawir (1997) in dictionary of al-Munawwir explained, commerce is a well-organized individual business activity to generate profits by selling merchandise or selling services to gain an advantage to meet community needs. Broaden commercial definition it is also define as the entire business process including agriculture, manufacturing, construction, circulation, transportation, communications, business and government personnel engaged in generating funds, marketing the product and services to users.

Mohd Nasir Omar (2005) also defines ethics or morals as a matter or one' dignity that makes self may perform an action spontaneously without any prior planning. He also mentions that there are two expressions as a reflection of moral (Akhlak) that is, bad habits such as: bad temper, fairness, and others, as well as a good feeling like: consistent, selfdiscipline, and others.

Ethics commerce according to the Business and Society Ethics and Stakeholder Management is stated as follows:

"Business ethics, therefore, is concerned with good and bad or right and wrong behavior that takes place within a business context. Concepts of right and wrong are increasingly being interpreted today to include the more difficult, and subtle questions of fairness, justice, and equity. "

Furthermore in this study, the term "commerce" as defined is a business or commercial activity, industry or finance activities, which are commonly associated with expenditure, or goods exchange services involving money from the entrepreneurs with certain business risk with a motive to gain a return. Additionally, the commercial may also be a human activity that involves spending, selling and buying goods and services to meet the community needs. The rationale given is a fair exchange between the parties involved.

From the various descriptions above, ethics in commerce is a rule in the form of commands and prohibitions in the human activities that covering expenses, selling and buying goodies and services to meet the needs of the community. Or in another mean, ethic in commerce is a mother of nature habit originally sourced from the principles and ideas of the good or bad in running a commercial business that may brought goodness and successful commerce.

\section{THE EPISTEMOLOGY OF MUHAMMAD PBUH' COMMERCE}

According to Runes (1971-1994) the term of epistemology was firstly used by J.F Ferrier in 1854, afterwards Runes explain that epistemology is the branch of philosophy, which investigates the origin, structure, methods, and validity of knowledge. Another scholar who tries to define epistemology is D.W Hamlyin, he said that epistemology is about the source and nature of knowledge, principles and assumptions, furthermore in general it 
should used as affirmation that person has the knowledge. Thus we should interpret epistemology simply as a source of knowledge or basic knowledge possessed by a person therefore we can determine it is a science.

Before becoming a Prophet, Muhammad PBUH was known as an honest and high ethical in every business that he conducts. Excellence strategy and ethical commerce is attained from his grandfather Abdul Muttalib (caretakers) and also the brother of his father, Abu Thalib (his caregiver after Abdul Muttalib died). In addition, the kindness of his good character and intelligence in trading is come from the heart that is clean and pure. Those clearness and pureness is because Jibril cleansed his heart with zam-zam water since the age of 5 years old.

Some scholars also contend that a Prophet was conserved from sin even though he has not been appointed as Prophet (Messenger of Allah) especially great sin. This aligns with the actuality in which the prophet known as honest and fair merchant, he never got involved with riba', did not sell liquor and sculpture and did not take an oath in the name of idols.

Accordingly, the core foundation of Muhammad PBUH' commercial knowledge before the era of his prophet hood was his pure heart and fine sustained from than reprehensible traits, in addition to the experience and teachings from his grandfather and his father' brother Abu Thalib. Righteousness attitude which inherited from his grandfather and his father's brothers then combined with his own experience in trading then adapted with his greatest morals, later then creating the high commercial ethics at that time. As a matter of fact, those ethics and values are the key features of his commercial concept and ultimately led Muhammad PBUH to the triumph in commerce.

\section{THE ENCOURAGE FACTORS ON WHY MUHAMMAD PBUH BECOME A BUSINESSMAN}

Muhammad PBUH that has been mentioned in this paper is Muhammad bin Abdullah bin Abdul Muttalib ibn Hashim bin Abd Manaf ibn Qusai bin Kilab bin Murrah bin Kinanah bin Khuzaimah bin Mudrikah bin Ilyas bin Mudar bin Nizar bin Adnan bin $\mathrm{Ma}^{\prime} \mathrm{ad}$. He was born on Monday 12 Rabi'al Awwal concurence with the elephant year that is dated April 20th, $571 \mathrm{AD}$. He died at the age of 63 years, on Monday the 13th of Rabi'alAwwal $11 \mathrm{H}$, or Isnin 8th June 632 CE.

Muhammad's life before the prophet hood era was a natural person. He lived and socialized as the society does at that time. However, throughout that time, Muhammad was capable to learn from the environment until he became a great man. He gained the title of al-Amin during his adulthood. There were many factors that encourage Muhammad chose to become merchants, they are: first, geographical factors of Arabia. It is located in a strategic region, as the connection hub of traffic economy between Sham (Jordan, Palestine, Libya), Yemen and Habasyah (Ethiopia). Therefore, most of the populations are have a profession as traders. The second was his economic factor, he has been an orphaned since he was a very young and grew up in the care of his less fortunate uncle, later then Muhammad helped his uncle economy as a shepherd, selling firewood and also help his uncle in trading. The third factor was the family where Muhammad lived with was a trader throughout generations. Muhammad PBUH's grandfather Abdul Muttalib was a rich merchants, his father Abdullah also a merchant, father' brothers (Ibn Abbas, Abu Talib, Abu Jahl) were merchants and a holder of commercial authority in Mecca back in that time. The fourth factor was, he married to a rich woman who is also a merchants named Siti Khadijah Ra.

\section{THE ETHICAL COMMERCE OF MUHAMMAD PBUH'}

Muhammad comes from a distinction personality family and is favorably respected by the Quraysh. His distinctive personality inherited from his grandfather, father and uncle. In addition, at age of 5 years old when he was under care of Halimah, as narrated by Anas bin Malik, two angels took him to zam zam, where they split open his stomach and took out his innards in a basin of gold, 
and washed them with zam zam water, then they filled his heart with wisdom and knowledge. This historical background is strongly believed as one of the factors that Muhammad had commendable qualities of childhood so that as a teenager he had bestowed the title Amin (honest) and Siddiq (reliable) by the Quraish. Honest and trustworthy nature that later became branch persona of Muhammad in the trade.

History recall Muhammad when he returned to Mecca, Khadija found her business was thriving under Muhammad' administration with full custody and dedication whilst this never happen before. Her aide, Maisarah alleged that during his time as Muhammad companionship, he had been very noble, possessed an analytical intellectual, truthfully speaking and trade with a full mandate. Khadija added, "During her partnership with Muhammad I always benefit a lot more rather than with my others partner".

Maisara, man-aide to Siti Khadijah man expresses the noble virtues and recompenses that Muhammad possessed during commercial evolvement. There were a time when the group had business trip, was always sheltered by white clouds so they do not sweltering, the trees that they are passed by also bowed. As they arrived at market, Muhammad was doing sell with smiles and fondness to the buyer he also informed they buyers the original price of goodies that are about to be traded and provided with the advantages and disadvantages of goodies so that the buyer be delighted. Then Muhammad present in detail the amount of goods were sold and the profits without slightest gap so Maisarah would record easily and report it to Siti Khadijah. This story makes Siti Khadijah be amazed and sympathized with Muhammad, because this has never been done by any merchants at the time.

Described in shahih kitab, when Muhammad PBUH had a meeting with Saib ibn Ali Saib, Muhammad welcomed him with enthusiasm by saying, "come-come, welcome my friend who used to be my partner", then Said ibn Ali Saib replied "welcome partner that always law-abiding in the calculations of the trade and never quarrel with me "(Judges in the shahih kitab). According to Hakim, Rabi ibn Badr was a slave of Thalha ibn Ubaidullah, he did trade cooperation with Muhammad. Later then one day he met The Prophet, and The Prophet asked, "Do you recognize me?" He replied, "You were my partner, the best partner, and you deceived me never and we have no argue". Another story also told by Abdullah ibn Abdul Hamzah: "I have bought something from the Prophet before he received a prophet hood mandate, and because there was still a matter with him, then I promise to deliver to him, but apparently I forgot. When I recalled three days later, I went to agreed places where we were supposed to meet and found him still waiting there. "He said," You have made me worried, I have been here for three days waiting for you "(HR. Abu Dawud). Those stories are proof of Muhammad PBUH' truly possessed a truthfulness, honor, compassionate, kept a promise and respect other people.

The primacy of moral and outstanding commerce ethic shown by Muhammad PBUH really impressed. Muhammad has done truthful transactions, fair and never upset customer. Besides honest, his gentle manner and affection to customers makes him easily earned the customers' hearts. By explaining the origin price of any goods without hiding the defects of goodies as well as provide the chance for buyers to bargain, finally create a good atmosphere during the mutual consent transaction. Whilst, Muhammad PBUH' very discipline in transaction record so that he recognizes sold items and profits gained, no slightest gap or miscalculation. This attitude will bring satisfaction would be for all sides involved, investor, traders and buyers.

\section{THE STRATEGY}

Strategies might define as a pattern of resource management that enables the company to sustain its performance (Barney, 1997). The strategy also defines as the overall disposition for the use of resources to create an advantageous situation so that the company ensured to achieve a desired goal. (Grant, 1995).

Meanwhile, Tull and Kahle (1990) define business strategy as a plan to achieve company' goals by developing sustainable competitive advantage through entered market and marketing programs that are used to serve the 
target markets. In addition, business strategy is setting up goals and objectives of a company in long terms, course of action and resources allocation needed to complete the goals and objectives.

To pursue the goal of commerce every merchants have different strategies to coup with the competition in the market they targeted. Equally to Muhammad, he has a strategy, which is very different to the Quraysh at that time until he always progress higher profits than his rivals. Not only high profits but Muhammad also can easily win the buyers' heart so that he succeeded the competition.

Al Siirah al Nabawiah and other books or journals described Muhammad as a poor slave and do not have their own capital to trade. He started his own business from baitulmal support capital to trade. But since there were so many people wanted to help Muhammad, such as widows, orphans even rich people of Mecca. They all wanted to provide capital for Muhammad. Muhammad even has to use the capital alternately. It all because of Muhammad is trustworthy and subtle in doing business.

Annas narrated that before becoming a prophet; Muhammad had offered a fabric made saddle and basins for drink, and then saying, "Who wants to buy this fabric made saddle and the basin for drink?" A man bid for one dirham, and Muhammad asked if anyone would pay higher prices. Later the other man bid at a price of two dirhams, and he sold it to him (Tirmidhi, Abu Dawud and Ibn Majah). It is a glance that Muhammad was very friendly and pleasant when conducts a trade and every price should be on a negotiable and consensual basis.

Maisarah, the man-aide of Siti Khadija when accompany Muhammad on a trip to Yemen perceives an experience with Muhammad, after his goods is sold out, he deliberately visited centers of garments and textiles there, and then buy fabrics and apparel and selling it in Mecca, while other traders return home to Mecca only carrying the rest of goods that have not been sold (Sofiyurrahman: 2014). Hence Muhammad had chances to gain more profits per trip. His talent in trade set circumstances that he possible to do something in market leads him to a higher profits than other merchants. This is what makes him earn wages and profit higher than others. He earned double profits when doing business in Busra market. That is why Khadijah offers him greater commission than they have both agreed upon earlier. (Al-Shalabi: 2004).

Many merchants are often envy Muhammad due to his unique method in trading. They even get angry with Muhammad, because he was unlike the other who did trading by justifies any means, or even they sometime become very deceitful to buyers, dishonest, took a false oath, hoarding goods, monopolist, selling defect items and conceal the defect from exposed, or commit disgraceful things. They angry because they sensed that many their buyer or customer will go to buy from Muhammad due to his attitude in trading, contrary to their method which to justify any means as long as they can sell their goods and profitable.

Al Siirah Nabawiah has recorded that the entire of Quraysh merchant depress Muhammad' business in Syria. Traders Qurays arranged to sell they're silk at lower price in order to hijacked Muhammad' sales. However Muhammad learns that Syria will have winter shortly thus Syrian would need the fabric, therefore he decided to sell it at the original price. During trip to Syria, Qurays merchant sold out their silk before it gets to Syria so that only Muhammad' silk are reached to Syria. Muhammad who possessed that sensed of market opportunities finally managed himself to gain a numerous profit, while Qurays could not. Muhammad' talents in doing business and trader were spread rapidly amongst traders and merchants in the continent, a business who uphold highest integrity and capabilities in business. Unquestionably that Muhammad was the great businessman at that time. This gloriousness becomes completed after he marries his joint venture, Siti Khadija then husband and wife starting running their business together.

Post married, Muhammad has more time and started to pay attention to the social life of the community. He found that the moral society was so devastating and he saw poverty everywhere. He used his wealth to support those who are less fortunate such as orphans, the elderly and widows who cannot 
afford what they should have. It is believed Muhammad use one-third out of his profit to help the poor, the other one-thirds to expand his business working capital (investment) and the rest one thirds brought home to support his wife and his children (Khamsa 2011). Although this argument is weak, but if we look at his generous attitude and compassion to the poor then this argument might be closer to the truth.

\section{THE UNIVERSAL VALUES}

Generally, Muhammad' business not so far differed with what jahiliyah people been doing in business. They all use the same currency such as dinar and dirham, selling the same items, except sculpture, khinzir (pig or anything related to pig ingredients which is prohibited in Islam), and khmer (alcohol drink which is also prohibited in Islam). In addition, Muhammad also avoid to get involved with riba' (usury) and it nurtures his wealth by practicing charities (philanthropy).

As we recognize that Muhammad PBUH is a great example of successful business whose practices the values of moral and ethical remarkably. Such moral and ethical commerce is certainly a new paradigm at that time and it is valuable used by Muhammad to win the competition at the time. The values (ethics) which is practiced by Muhammad PBUH are as follows:

- Value of honesty, Muhammad PBUH was an al-amin (trustworthy) because he never speaks but the truth, a promise keeper. He always carry his goods in good state, exposed the defects of goods, and mention. He prefers to conduct buy and sell of transparency basis.

- Value of mandate, He is famous as a trusted person (amanah). He has a habit of scripting the details of his expenditures and revenues during a business process to avoid miscalculation. This will ease Muhammad PBUH to generate a report which is will be used in the future both for him and the investor since they will be use the report to determine wages and portion of commission.

- The value of justice, he always serve and respect all people without any discrimination. Fairness in weight is a must and avoiding argument with his customer would always imperative.

- The values of modesty and affection. Muhammad was always creating a pleasant atmosphere when doing transaction with his customer. He always smiled and greeted sincerely. Annas bin Malik narrated that before a Prophet, Muhammad had offered a fabric made saddle and basins for drink, and then saying, "Who wants to buy this fabric made saddle and the basin for drink?" A man bid for one dirham, and Muhammad asked if anyone would pay higher prices. Later the other man bid at a price of two dirhams, and he sold it to him (Tirmidhi, Abu Dawud and Ibn Majah).

- Price is negotiable and based on mutual consent. Before transaction, he always explain the goods according to its actual condition hence, so buyers may bid at the desired price what ever the price that has been agreed he never refused any slight of profit.

- Never involved in usurious practices', during his business journey even Muhammad got capital from baitulmal (treasury) or from the orphans and widows who were not capable of manage their own possessions. His often run his business deal under with mudaraba scheme (Muhammad as mudarib). Consequently he was never involved in usurious practices as conducted by jahiliyyah as their main business.

- Khamr, sculpture, blood and carcasses were items that he never sells. Muhammad only sells goods such as clothing, container, grain, fragrant, as well as miscellaneous home tools. His Majesty also did not sell statues, never took an oath in the name of idols, even he avoided if there are places where idols were being manufactured.

- No arguement with partners and buyers. Honesty, decency and fairness will bring his partners and buyers into satisfaction level. On one occasion he had a meeting with Saib ibn Ali Saib, Muhammad welcomed him with enthusiasm by saying, "come-come, welcome my friend who used to be my partner", then Said ibn Ali Saib replied "welcome partner that always law-abiding in the calculations of the trade and never quarrel with me "(Judges in the shahih kitab). According to 
Hakim, Rabi ibn Badr was a slave of Thalha ibn Ubaidullah, he did trade cooperation with Muhammad. Later then one day he met The Prophet, and The Prophet asked, "Do you recognize me?" He replied, "You were my partner, the best partner, and you deceived me never and we have no argue".

- Strictly never took an oath in the name of an idol in order to heighten up his business and he will refuse if someone asked him to swear in the name of idols.

- Hoarding goods is not allowed (ikhtisar). He could have sold goods at higher price, but he prefers to sell at normal price (based on agreed price between parties involved) that's why his goods always sold out within short period.

- Defect item replacement policy. It is normal after transaction, maybe after they went home buyer might aware of defect on the item he bought, Muhammad PBUH' willing to replace the defect one with perfect one as long as the buyer present a logic explanation to claim his purchase.

- Avoiding the competition on price. He chose to sell at normal price rather to lower the price in order to compete with other merchants.

- Any slight profit will do. He never bear any loses throughout his business journey.

- Pay wages on time or before his workers' sweat dries.

- Prophet is very generous to others. As mentioned above willing to share his wealth to those who needed, and sometimes he settled whomever unable to pay his debts.

Muhammad PBUH' values (ethics) are took-places valid prior to the prophet hood period (before the revelation). These values is a mother of nature, hence this can be applied as a whole (universal) without limitations of religion and state.

\section{THE ETHICAL COMMERCE: BETWEEN MUHAMMAD PBUH' AND CONVENTIONAL}

Conventional and commerce economics study which been pioneered by Adam Smith (1776) was a free moral and ethical' economics and commerce. Thus, conventional commercial of neoclassical is based on the maximization of material satisfaction and personal interests, resulting in less attention toward welfare and social interests. Recently scientists in the West are aware that an ethics in the company is essential, since it has a positive relationship with the company's progress. For example, Vardi (2001), showed a negative relationship between the application of ethics and worker' abnormality behaviors. These abnormality behaviors occurred due to poor application of ethics in the workplace and this will eventually loss likelihood for the corporate.

Relationship between business ethics and financial performance (work of finance) has also become an important issue in the world of commerce in the last twenty-five years. A number of researchers have found the result that the relationship between the two is positive. According to Bernard Schwab, to create an ethical company will cost a high budget investment, that fun will be used to handle a CSR (Corporate Social Responsibility). In addition the company also had to conduct work ethic or other internal programs to strengthen the ethics amongst employee in the company.

Founder of General Electric, Reginald Jones, (1917 - 2003), stated that the performance of the organization with ethics are closely related. Likewise with the results of the study by the Performance Group, a consortium comprised of Volvo, Unilever, Monsanto, Imperial Chemical Industries, Deutsche Bank, Electrolux and Gerling, found that the development of environmental friendly products and also improvement in environmental compliance may raise the companies' EPS (earnings per share, increasing in profits and alleviate the chances to get a contract or investment agreement. It was also found that corporate ethics affect the social life of the company that may reflect to the company's performance generally.

From the issues mentioned above, the modern western economic experts began to profound the incorporate ethics into the theories of economics and commerce. Some of western economists are still as hesitate as whether morality has no place in commercial 
activities or contrary. The reason this to be put forward is because ethics is a discipline that consists of standards about what is right or wrong, good or bad, so it is considered incompatible with the system and the business structure.

Apart from distinctive views of western' economist above, particular of modern western economic experts have made some business ethical standards as the reference for conventional business ethics today. An instance, Kohlbeng a Western scientists have been giving some principles of ethics in business, including; First, the principle of the benefit, secondly, the principle of human rights, and the third principles of justice. Mathusita also affirmed a similar thing; he explained the purpose of business is not solely on profit but to serve public purposes while profit making is naught but evidence of public confidence in the activities of one enterprise business.

Referring Mahmoedin (1996: 81) ethical business has 7 principles namely; 1 ) is free, 2 ) responsibility, 3) truthful, 4) good endeavors, 5) fair, 6) respectful, 7) informative. Keraf (1998: 56) composed that business ethics as follows; the principle of autonomy, the principle of honesty, the principle of justice, mutual benefit and the principle of noble moral integrity. According to Keraf (1998) ethical principles that apply in commerce are the implementation of ethical principles in general. Thus, the principles of a common ethical commerce are described as follows:

Firstly, the principle of autonomy is a human attitude and his ability to make decisions and act upon his conscious about what he thinks is right to do. Autonomous merchants are those who are fully aware of what his duty in the world of commerce.

Second, the principle of honesty. Honesty is an ethical principle of business; merchants are required to be trustful in every contract of sales and joint venture. Undeniable that this principle is the most problematic aspect because there are many merchants who like to trick or fraud.

Thirdly, the principle of fairness specifically that everyone should be treated equally, accordance with the rules of responsible fair and rational criteria. Correspondingly, the principle of justice demands that every person in commercial activities need to be treated inline with their respective rights. Justice demands that there should be no one that his neither rights nor interest is violated.

Fourth, the principle of mutual benefit, this principle is intended to keep the commerce is always efficiently managed and benefit all parties involved. This principle is mainly to accommodate the nature and purpose of business. Thus, in a competitive business, this principle requires that business competition must necessarily ascent to a win-win solution.

Fifth, the principle of moral integrity. It is a principle that holds up internal demand to sustain in an ethical and maintaining a respectable brand image of his company. Likewise, this principle is a merchant' or companies' self-demand and a self-boost to be the best and to be proud of.

From all the commercial ethical principles above, Adam Smith considered principle of justice as the ultimate principle. Meanwhile, Hatta looked at divine justice, so it remained not only the mundane dimension or the present, but also here after dimension. Those are the principles of conventional business ethics according to some western economist. Hence we might see the distinction and similarities with the principles of ethical commerce era before the prophet hood of Muhammad PBUH on the principle of autonomy, the principle of honesty, justice, integrity and the principle of mutual benefit seen as resemblance to Muhammad commercial ethics, but if we examine profoundly then we will find a very clear distinctions.

Among the distinctions, the most noticeable different between the ethics of commerce Muhammad era before the prophet hood and modern conventional commercial ethics are as follows; First, the "principles of justice", which in the conventional perspective of justice meant that everyone should acquire the same treatment, while justice according to Mohammed PBUH has a broader meaning which all people should have equal treatment in the economy, monopoly is not allowed or hoarding goods in the purpose of speculation. Those attitude can harm the the consumer' rights. 
Second, the principle of moral integrity, ethics demand that the conventional commerce merchants to maintain the integrity of companies that may be the company become debuted and reliable or merchants have to maintain the good name of the company in any possible means. Muhammad PBUH has a moral integrity that comes out of him, his possessed an honest aptitude, trustworthy and fair and that is great strength of integrity. His natural habit was that he always explains the advantages and disadvantages of his goods, pricing would be at bargaining level and are willing to replace the goods that are returned for accepted reason. These are an example of actual high integrity. In addition, he also only sells what considered flawless goods without defect and not to sell the carcasses, pork, liquors and sculpture, which are against the sharia. These characters are hard to find in the modern conventional commercial ethics. Thus, in terms of integrity we can conclude that Muhammad is advanced.

Third, Riba' (usury), in modern conventional commercial ethics is allowed. E ven usury' is a major strength of conventional commerce. In a capitalist system, interest rate is the life support of conventional business. Whilst, usurious in the economic will bring major impact in macro economy. There are 365 economic crisis cases since Great Depression prevailing in the 1930s. Muhammad PBUH obtained capital from people voluntarily and adopt mudharaba and profit sharing scheme, hence he never stepped involved in usurious scheme.

Fourth, the principle of justice in Muhammad PBUH' commercial substances also concerns on economic factors distribution to the public, and is not found in the ethics and principles of modern conventional economics. These concerns cover the purpose of the commercial itself that is to serve public purposes. As known, Muhammad PBUH use some his wealth that obtained from his business are for helping the poor and the less fortunate. Moreover as described above, the prophet did not do hoarding so that the economy performed well continually.

From the analysis above, it appears clearly that the ethical commerce of Muhammad
PBUH is already thorough and more advanced rather than conventional commercial during the Jahiliyah system. This is due to the ethics of commerce Muhammad is sourced from his own noble character himself, while conventional commercial ethics sourced than reasoning and agreement of the experts who may not necessarily be well practiced, because ethics itself is an originally natural actualspontaneous act.

\section{FORMULATION}

Ethics shown by Muhammad before the prophet hood was so unprecedented and attained from his clean heart and noble character. While conventional commerce during jahiliyah era was unethical, deprived of commercial law standard hence business is conducted liberally and without value. Likewise the modern conventional commerce, but the conventional commerce has emerged awareness about the importance of ethics in commerce. Although there are disagreements about the need for ethics in commerce entity, but some of western economic experts have compiled some principles of ethical principles such; the principle of autonomy, the principle of honesty, fairness, integrity principle and the principle of mutual benefit.

The ethical principles of the modern conventional business have similarities with commercial ethics by Muhammad PBUH such as the principle of autonomy, honesty, fairness and integrity. Nevertheless, the principles commerce of Muhammad is more complete and advanced; the principles of trust, the value of modesty and tenderness, the price is determined on the basis of bargaining and consensual, not involved in usurious practices', not selling a liquor, sculpture, blood and carcasses, avoid argument with partners and buyers, never took an oath in the name of idols, hoarding goods, is not allowed, defect goods replacement policy, avoid competition on price, small profit is acceptable, pay the workers' wages on time (before his sweat dries), and economic factors distribution to the community (philanthropy). Some proportions of these business ethical principles are not acknowledged by modern conventional business. 
The beauty and honor of these values (ethics) commercial took place naturally originally and Muhammad PBUH has proved a triumph on his commerce. Henceforth, the values (ethics) commercial are universal ethics since it is not associated with any religion and the state and may be practiced by anyone who wants to be successful businessman.

\section{REFERENCES}

Abu Hamid Muhammad Ibn Muhammad al-Ghazzali. 1976. Ihya' Ulum al-Din, Jilid. 3 Kaherah: Muassasah al-Halabi wa Shurakauhu li al-Nashr wa al-Tawzi'.

Abu Muhammad Abdul Malik Ibnu Hisyam ibnu Ayyub al-Humairy. 1995. al-sirah alnabawiyah, Selangor: Akbar Media Syarah \& Tahqiq.

Abdul Ghafar Ismail, et al, 2012. "Krisis Zon Eropah: Kebenaran dan Pengajaran Kepada Sistem Kewangan Islam. Pusat Islam Iskandar, Johor Bahru.

Achmad Charris Zubair. 1995. Kuliah Etika. Jakarta: Rajawali Press.

Adrian Blundell-Wignal. 2012. Solving the Financial and Sovereign Debt Crisis in Europe, OeCD Journal: Financial Market Trend. Vol. 2011-Issue 12.

Afzalurrahman. 2000. Muhammad As a Trader. Jakarta: Yayasan Swarna Bhumy.

Ahmad Munawwir. 1997. Kamus al-Munawwir, Arab Indonesia, 2nd Ed. 14th printed. Jakarta: Pustaka Progresif.

Ahmad Tafsir. 2009. Filsafat Umum Akal dan Hati Sejak Thales Sampai Capra. Bandung: Remaja Rosdakarya.

Alfred Chandler. 1962. Strategy and Structure. Cambridge, Ma: MIT Press.

Anderson, Gary M. 1988. "Mr. Smith and the Preachers: The Economics of Religion in the Wealth of Nation," Journal of Political Economy, Vol. 96, No. 5.

Anwar Abbas. 2010. Bung Hatta dan Ekonomi Islam; Menangkap Makna Maqhasid al Syariah. Jakarta: Kompas Media Nusantra.

Arif Mulyadi. 2002. Pengantar Filsafat Islam: Sebuah Pendekatan Tematis. Bandung: Mizan, Cet. II.

Carol W. Lewis.1991. The Ethics Challenge in Public Service. California: Jossey-Bass Publishers.
Gunardi Endro. 1999. Redifinisi Perniagaan: Suatu Penggalian Etika Keutamaan Aristoteles. Jakarta: Pustaka Binaman Pressindo.

Heri Sudarsono. 2004. Konsep Ekonomi Islam. Yogyakarta: Ekonosia.

Ibn Kathir. 1980. Tafsir al-Quran al Adhim. Beirut: Dar al Fikr.

Ibnu Manzur t.ht., Lisan al-Arab. Juz ke-5. Hadharah: Dar al-Maarif

Ibrahim Anis, et al. 2001. Mu'jam al-Wajiz: Mesir: Jumhuriyyah al-Misri al-Arabiyyah.

Kamus Dewan. 2002. ed. Ke-3. Kuala Lumpur: Dewan Bahasa Dan Pustaka.

Karen Armstrong. 2007. Muhammad Nabi Zaman Kita. Yogyakarta: Beranda.

K. Berten. 2002. Pengantar Etika Perniagaan. Yogyakarta: Kanisius.

Kenneth Lux. 1990. Adam Smith's Mistake; How a Moral Philosopher Invented Economics and Ended Morality. New York: Shambhala.

Keraf, Sonny. 1997. Bisakah Bisnis Berjalan Tanpa Moralitas. Yogyakarta: Kanisius, Edisi Khusus.

Keraf, Sonny. 1998. Etika Bisnis, Tuntutan dan Relevansinya. Yogyakarta : Kanisius.

Kwik Kian Gie, dkk. 1996. Etika Bisnis Cina: Suatu Kajian Terhadap Perekonomian di Indonesia, Jakarta : Gramedia Pustaka.

Makalah Anas Khoiruddin dkk. Sejarah Bangsa Arab Pra Islam, diunduh dari www.docstoc. com pada 26 Juli 2011

Makalah Anas Khoiruddin dkk. Sejarah Bangsa Arab Pra Islam, diunduh dari www.docstoc. com pada 24 Februari 2016

M. Abdul Karim. 2007. History of the Muslim Thought and Civillization, terj. Tim Pustaka Book Publisher, Sejarah Pemikiran dan Peradaban. Yogyakarta: Pustaka Book Publisher.

M. Quraish Shihab. 1994. Membumikan alQur'an. Bandung: Mizan.

Mohd Nasir Omar. 2005. Akhlak dan Kaunseling Islam. Kuala Lumpur: Utusan Publications.

Moenawar Cholil. 2006. Kelengkapan Tarikh Nabi Muhammad, Jil. 1. Jakarta: Gema Insani Press.

M. Umer Chapra. 2000. The Future of Economics: An Islamic Perspective, Islamic Economics Series: 2, United Kingdom: Tha Islamic Foundation.

Mustafa Haji Daud. 1996. Etika Pengurusan. Kuala Lumpur: Utusan Publication. 
Majid Fakhri. 1996. Etika Dalam Islam. Yokyakarta: Pustaka Pelajar dan Pusat Studi Islam-USM.

Muhammad ibn Habib Bagdadi. 1942. alMuhabbar, Da'irah Al-Ustmanyiyah, Hyderaba, India: Deccan.

Muhammad bin Yasar ibn Isaac. 2002. Sirah Ibn Ishaq. Surakarta: Muhammadiyah University Press.

Muhammad bin Alwi al-Maliky. 1994. alBushrā fì Manāqib al-Sayyidah Khadījah alKubrā. Surabaya: Barar al-Tsaqaf,

M. Suyanto. 2008. Muhammad Business Strategy and Ethics. Yogyakarta: Andi Offset

Nor Azzah binti Kamri. 2002. Etika Pengurusan Islam dan Konvensional, Suatu Analisis Perbandingan, Jurnal Syariah Vol.10, No. 2.

Oliver Leaman. 1999. A Brief Introduction to Islamic Philosophy. Cambridge: Polity Press

Osman Bakar. The Spiritual and Ethical Foundation of Science and Technology in Islamic Civilization, http://i-epistemology.net/ science-a-technology /845-the-spiritualand-ethical -foundation - of-science-andtechnology-in-islamic-civilization.html

Peter Baelz. 1977. Ethics and Belief. London: Sheldon Press.

Philip K. Hitti. 2002. History oh The Arabs. New York: Palgrave Macmillan

Qairunnisa Khamsa. 2011. Bisnis Tanpa Rugi Ala Rasulullah SWT. Makasar: Arus Timur.

Qardhawi Yusuf. 2003. Norma dan Etika Ekonomi Islam. Jakarta: Gema Insani Press

Rahardjo, Dawan. 1995. "Etika Bisnis Menghadapi Globalisasi dalam PJP II", Yogyakarta: Prisma.

R. Sims. 2003. Ethics and Corporate Social Responsibility-Why Giants Fall. C.T.: Greenwood Press.
Robin Snell.1993. Developing Skill for Ethical Management. London: Chapman \& Hall.

Ronald M. Green. 1994. The Ethical Manager: A New Method For Business Ethics. New York: Macmillan College Publishing Company, Inc. Rus'an. 1981. Lintasan Sejarah Islam di Zaman Rasulullah SAW. Semarang: Wicaksana.

Sayyed Nasr and Oliver Leaman, 1996. History of Islamic Philosophy. London: Routledge.

Spiegel, H.W. 1991. The Growth of Economic Thought, $3^{\text {rd }}$ ed. Durham, NC: Duke University Press.

Sahih al-Bukhari. 1387H. Muhammad ibnu Ismail al-Bukhari (m.256H). India: Maktabah Rahmaniyyah.

Sahih Muslim. 1376H. Muslim ibnu Hajjaj alQurasyi. India: Maktabah Rasyidiyah.

Smith, Adam. 1996. An Inquiry into the Nature and Causes of the Wealth of Nation. New York: The Glasgow Edition.

Smith, Adam. 1982. Theory of Moral Sentiments. Ed. A.L. Macfie and D.D. Rafphael. Indianopolis: Liberty Press.

Sri Nawatmi.2010. Etika Bisnis Dalam Perspektif Islam. Fokus Ekonomi (FE), April 2010, Vol. 9, No.1, ISSN: 1412-3851.

as-Syaikh Taqiyuddin an-Nabhani. 2003. AsSyakhshiyyah al-Islamiyyah al-Juz' al-Awwal, Dar al-Ummah. Beirut: cetakan Muktamadah.

Syeikh Sofiyurrahman Al-Mubarakfuri. 2013. Sirah Nabi Ar-Rahiq al-Makhtum. Selangor: Kemilau Publika Sdn.Bhd.

Y. Vardi. 2001. The Effects of Organizational and Ethical Climate as on Misconduct at Work, Journal of Business Ethics, Februari 2001, 29,4, ABI/INFORM Global.

Zen Abdurrahman. 2011. Strategi Genius Marketing ala Rasulullah. Jogjakarta: Diva Press. 